\title{
First Report of Clavinema mariae (Nematoda: Philometridae) in Cultured Rockfish, Sebastes schlegeli, in Cheonsuman (Bay), the Republic of Korea
}

\author{
Hyun-Ja Han', Jung Soo Seo', Jeong Su Park², Haeng Lim Lee², Han Gill Seo', Sung Hee Jung1', Se Ryun Kwon², \\ ${ }^{1}$ Pathology Division, National Fisheries Research and Development Institute, Busan 46083, Korea; '2Department of Aquatic Life Medical Sciences, \\ Sunmoon University, Asan 31460, Korea
}

\begin{abstract}
In July 2012, philometrid nematodes were discovered in cultured rockfish (Sebastes schlegeli) in Cheonsuman (Bay), the Republic of Korea. The nematodes were detected in the epithelial tissues of the rockfish and were identified as Clavinema mariae based on morphological studies using light and scanning electron microscopy. They revealed the characteristics same as previously identified C. mariae, notably having a long body with narrow posterior half, no caudal projection, a cylindrical-shaped esophagus, a well-developed anterior bulbous part of the esophagus, cephalic papillae, and a dorsal esophageal gland. This is the first confirmation of $C$. mariae infection in rockfish in Korea.
\end{abstract}

Key words: Clavinema mariae, nematode, rockfish, Sebastes schlegeli, Cheonsuman, Korea

Sebastes schlegeli, commonly known as the rockfish, is an important aquaculture species in the Republic of Korea (= Korea). Commercial production of rockfish increased in the late 1990s and reached a maximum of 35,564 tons in 2007 [1]. Presently, the rockfish and olive flounder (Paralichthys olivaceus) are the predominant aquaculture fish species in Korea. In July 2012, nematode parasites were found for the first time in the epithelial tissue of the rockfish from Cheonsuman (Bay), located on the Yellow Sea coast of Korea. Seo et al. [2] reported some nematode infections (species not determined) from rockfish in Cheonsuman throughout the year (examined monthly from May 2013 to April 2014, with the exception of October 2013). Those nematodes made skin wounds as they emerged from their rockfish hosts, which led to bacterial infections, including those caused by Photobacterium damselae, Vibrio spp., and Streptococcus iniae. In August 2013, accumulated mortalities of 1.4-22.4\% were recorded in the infected rockfish.

Approximately 150 of the 166 nematode species belonging to the superfamily Dracunculoidea are known to parasitize approximately 300 fish species [3]. Philometrid nematodes (fam-

\footnotetext{
• Received 26 August 2016, revised 7 February 2017, accepted 26 February 2017.

*Corresponding author (srkwon@sunmoon.ac.kr)

(C) 2017, Korean Society for Parasitology and Tropical Medicine

This is an Open Access article distributed under the terms of the Creative Commons Attribution Non-Commercial License (http://creativecommons.org/licenses/by-nc/4.0) which permits unrestricted non-commercial use, distribution, and reproduction in any medium, provided the original work is properly cited.
}

ily Philometridae) are pathogenic parasites of commercially important wild or cultured fish hosts. Among these parasitic species, 26 have been detected in marine and freshwater fishes in Japan, most of which belonged to 3 genera, Clavinema Yamaguti, 1935, Philometra Costa, 1845, and Philometroides Yamaguti, 1935 [4]. However, at present, there have been no confirmed cases of these parasitic nematodes in cultured rockfish. To date, Huffinanela spp. [5] and Huffinanela canadensis [6] have been isolated from the skin of rockfish (Sebastes spp.) from the Pacific Ocean near the coast of Vancouver Island, British Columbia, Canada. In addition, anisakid nematode infections have been reported in the muscular and visceral organs of several species of the genus Sebastes [7-10].

The present study was performed to identify a philometrid nematode (identified as Clavinema mariae) discovered in the epithelial tissue of cultured rockfish in Cheonsuman, Korea using light and scanning electron microscopic observations. The results provided morphological information on this worm, which may be associated with rockfish mortalities in Cheonsuman Bay.

During the period April 2014 to June 2016, nematode worm samples were collected every other month from the epithelial tissues of cultured rockfish, S. schlegeli, in Cheonsuman, which is located on the Yellow Sea coast of Korea $\left(126.42^{\circ} \mathrm{N}, 36.60^{\circ} \mathrm{E}\right)$. The fish were initially examined macroscopically to inspect for infection with female nematodes. Having detected infection, 
scalpels, dissection scissors, and forceps were then used to cut or tear host tissue away from the parasites so that they could be collected gently with forceps. The nematodes were fixed in $70 \%$ ethanol and then cleared with glycerin for light microscopic examinations. Specimens used for scanning electron microscopy were transferred to $2.5 \%$ glutaraldehyde solution and then post-fixed in $1 \%$ osmium tetroxide, dehydrated through a graded ethanol series, critical point dried, and sputter-coated with gold. The specimens were examined using a JEOL JSM6400 scanning electron microscope (Tokyo, Japan) at an accelerating voltage of $20 \mathrm{kV}$. For histopathology, infected tissues were fixed in $10 \%$ buffered formalin and embedded in paraffin, sectioned at $5 \mu \mathrm{m}$, stained with hematoxylin and eosin, and examined by a light microscope.

Nematodes were mainly found in the operculum, pectoral fin, dorsal fin, and oral cavity of the fish. Worms isolated from the fish were red in color (Fig. 1). In a histopathologic specimen of pectoral fin connective tissues, we observed gravid nematode females containing numerous eggs within their uteri (Fig. 2).

A total of 30 specimens collected in June 2016 were used for observation and measurement (Table 1). The body of subgravid females was distinctly narrower in its posterior half. Body length ranged from 22.0 to $31.0 \mathrm{~mm}$, and the maximum width ranged from 0.59 to $0.70 \mathrm{~mm}$. The cephalic end was rounded, with an elevated esophageal bulb region. The mouth was slightly depressed, and small cephalic papillae were observed (Fig. 3D). The anterior end of the esophagus formed a conspicuous, strongly muscular bulb that was well separated from the cylindrical portion of the esophagus (Fig. 4A). Bulb length and width were $0.09-0.30 \mathrm{~mm}$ and $0.10-0.34 \mathrm{~mm}$, respectively. The esophagus opened into the intestine via distinct valves. The length of the entire esophagus, including the anterior bulb, was $0.40-1.07 \mathrm{~mm}$. A nerve ring encircled the anterior end of the cylindrical portion of the esophagus. The duct of
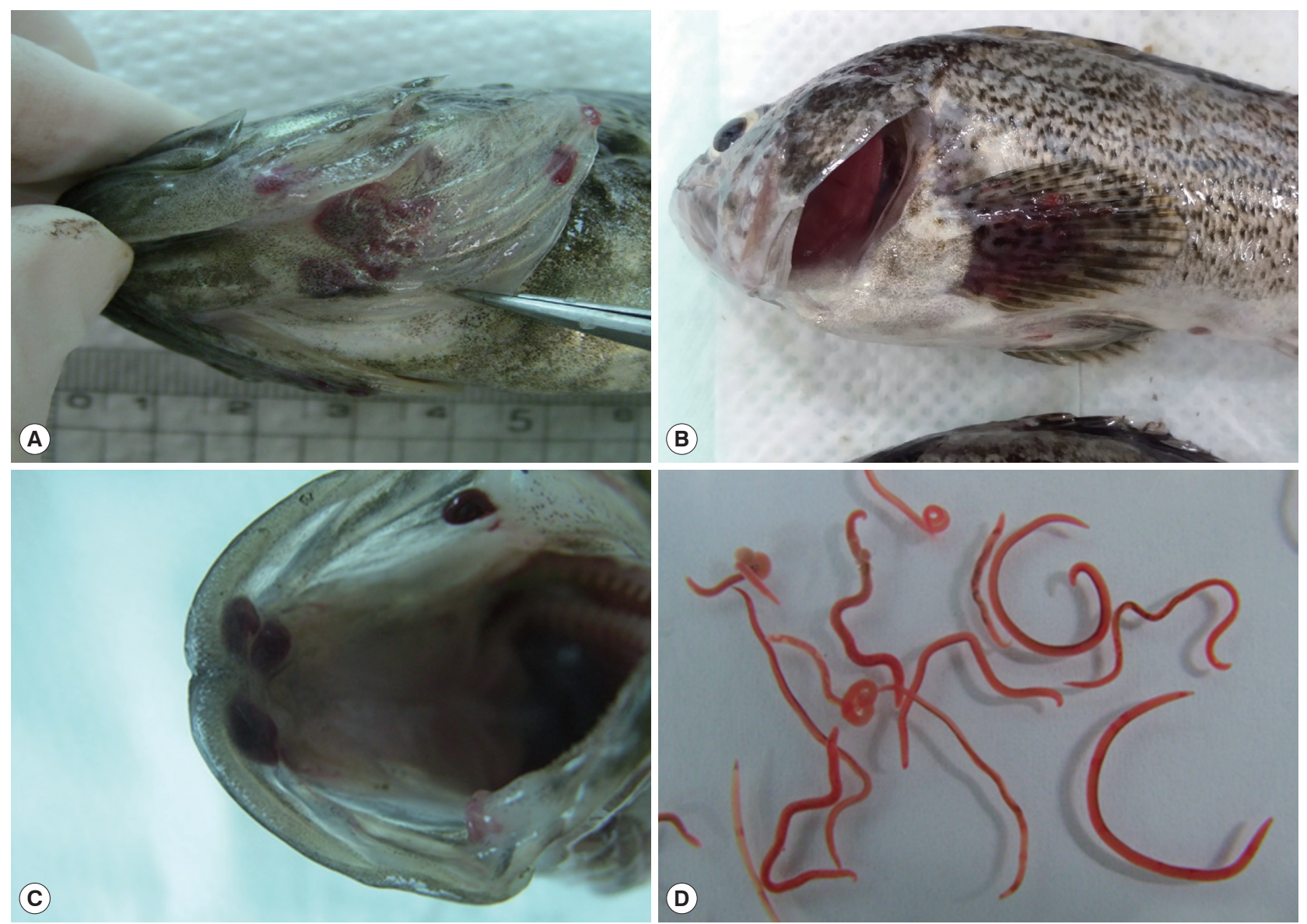

Fig. 1. Body locations of rockfish, Sebastes schlegeli, infected with Clavinema mariae, showing the operculum (A), pectoral fin (B), oral cavity wall (C), and isolated nematodes (D). 
the dorsal esophageal gland was also observed. The intestine was wide throughout its length and attached by a short translu- cent ligament to the ventral body wall near the posterior aspect of the body (Fig. 4C). The intestinal width was 0.26-0.50
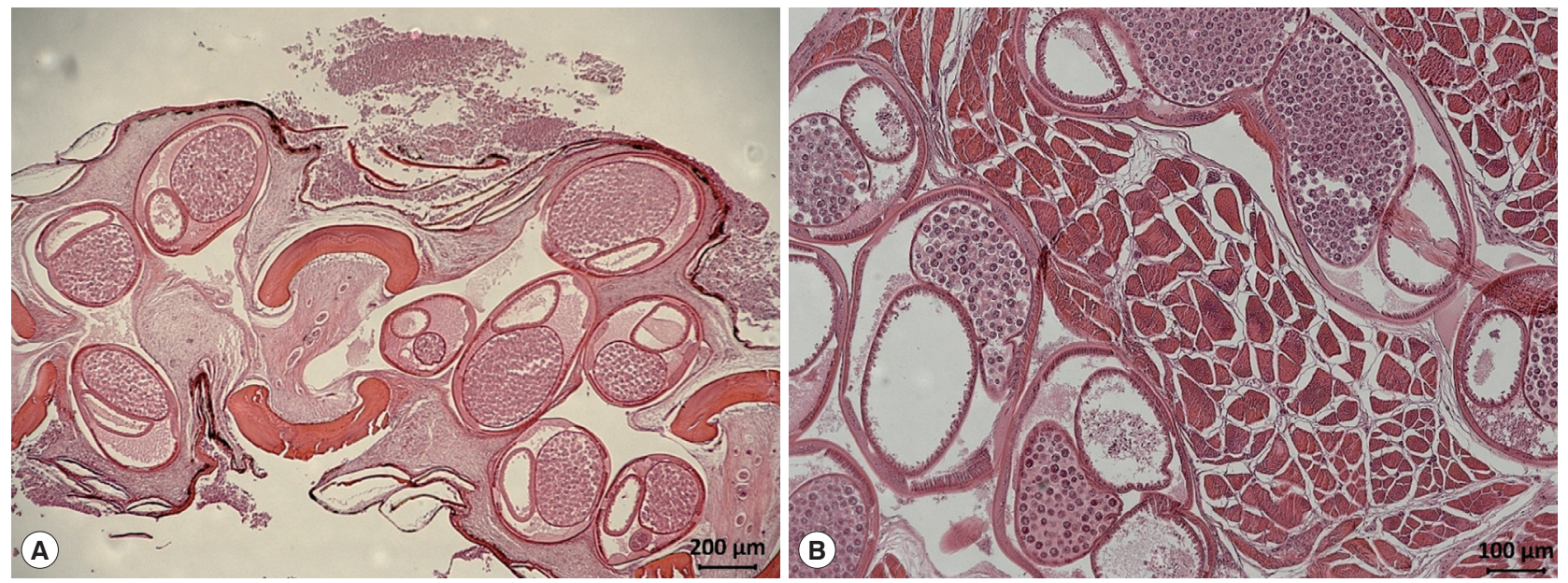

Fig. 2. Histological findings of encapsulated C. mariae in the connective tissue of the pectoral fin of S. schlegeli (A) and its basal muscle (B). Numerous eggs are observed in the uterus of gravid females (hematoxylin and eosin stained).
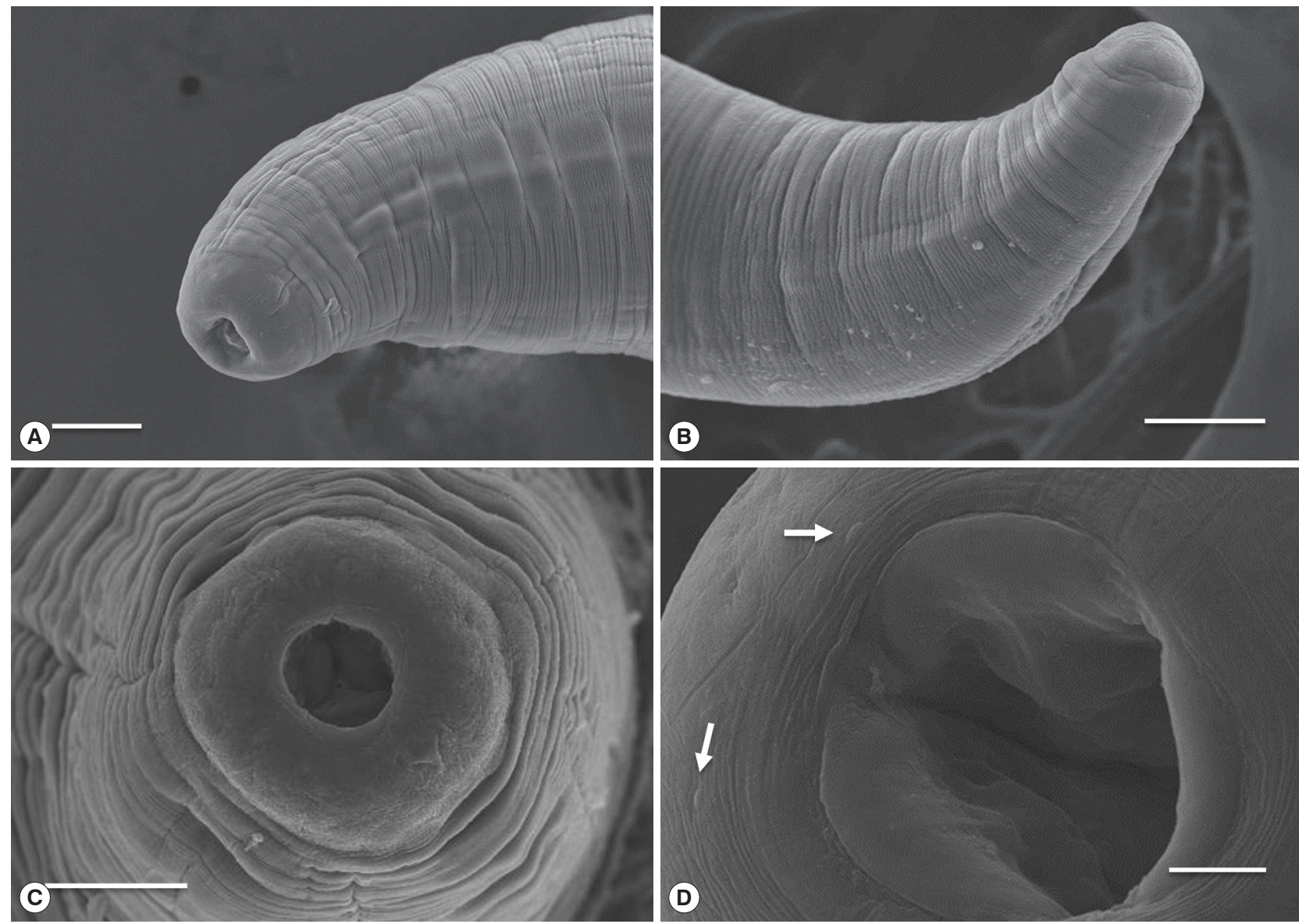

Fig. 3. Scanning electron micrograph of $C$. mariae. Lateral view (A) and apical view (C) of the cephalic end of a female. Lateral view of the posterior end of a female (B) and oral aperture and cephalic papillae (arrow) (D). Scale bars: $A, B$, and $C=50 \mu m ; D=10 \mu m$. 


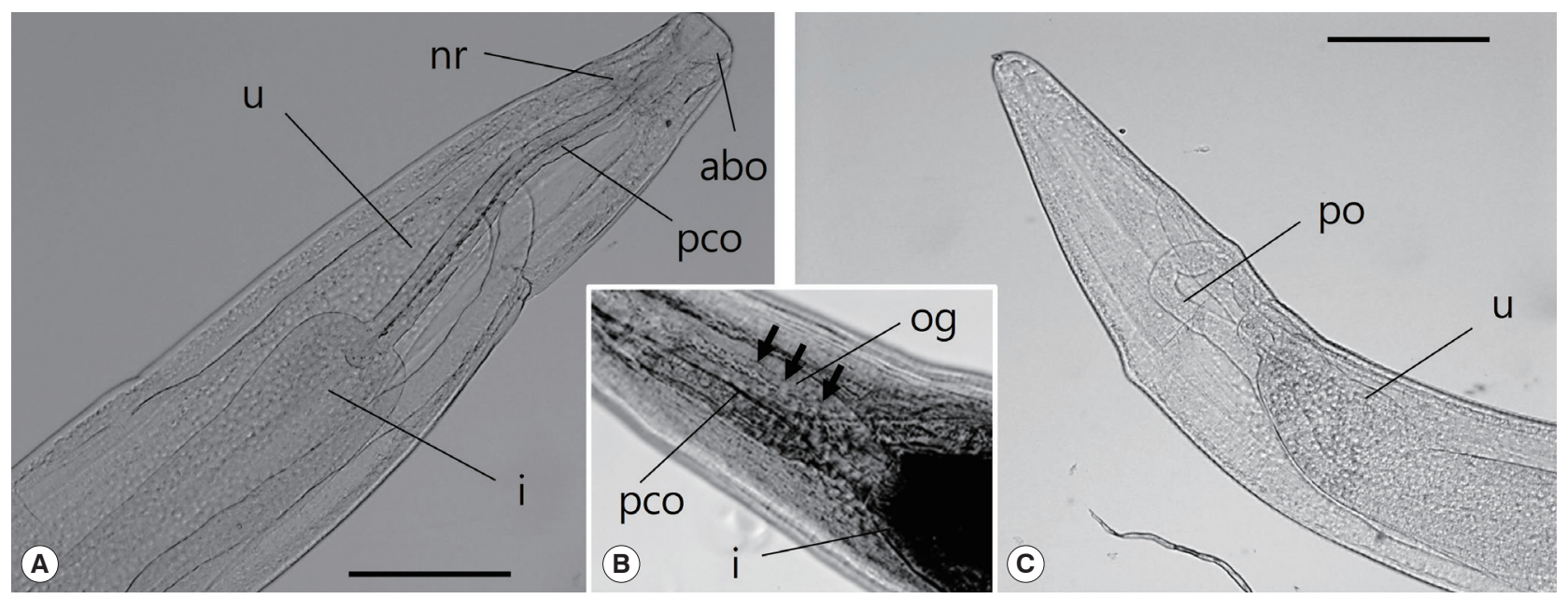

Fig. 4. Light microscopic observations of $C$. mariae, anterior part (A, B) and posterior part (C). The arrow indicates the esophageal gland. abo, anterior bulbous part of esophagus; i, intestine; nr, nerve ring; og, esophageal gland; pco, posterior cylindrical part of esophagus; po, posterior ovary; u, uterus. Scale bar $=50 \mu \mathrm{m}$.

Table 1. Morphometric data of Clavinema mariae (unit, $\mathrm{mm}$ )

\begin{tabular}{|c|c|c|c|c|c|c|c|c|}
\hline & $\begin{array}{l}\text { Body } \\
\text { length }\end{array}$ & $\begin{array}{l}\text { Body } \\
\text { width }\end{array}$ & $\begin{array}{l}\text { Length } \\
\text { of entire } \\
\text { esophagus }\end{array}$ & $\begin{array}{l}\text { Length of } \\
\text { bulb }\end{array}$ & $\begin{array}{l}\text { Width of } \\
\text { bulb }\end{array}$ & $\begin{array}{l}\text { Length of } \\
\text { cylindrical part } \\
\text { of esophagus }\end{array}$ & Hosts & Distribution \\
\hline $\begin{array}{l}\text { Clavinema mariae } \\
\text { (present material) }\end{array}$ & $22-31$ & $0.59-0.70$ & $0.40-1.07$ & $0.09-0.30$ & $0.10-0.34$ & $0.20-0.96$ & Sebastes schelgeli & $\begin{array}{l}\text { Cheonsuman of } \\
\text { Korea }\end{array}$ \\
\hline $\begin{array}{l}\text { Clavenema mariae } \\
\text { (Layman [16]) }\end{array}$ & $16-32$ & $0.73-0.81$ & 0.95 & 0.22 & 0.24 & 0.73 & $\begin{array}{l}\text { Protopsetta herzen- } \\
\text { steini } \\
\text { Limanda schrenki }\end{array}$ & $\begin{array}{l}\text { Peter the Great } \\
\text { bay }\end{array}$ \\
\hline $\begin{array}{l}\text { Clavinema mariae } \\
\text { (Yamaguchi et al. [13]) }\end{array}$ & $4.9-18.3$ & $0.9-1.4$ & - & $0.34-0.44$ & $0.26-0.39$ & $0.76-1.21$ & $\begin{array}{l}\text { Rhinogobius pflaumi } \\
\text { Chaeturichys sciistius }\end{array}$ & $\begin{array}{l}\text { Hiroshima bay of } \\
\text { Japan }\end{array}$ \\
\hline $\begin{array}{l}\text { Clavinema mariae } \\
\text { (Machida [14]) }\end{array}$ & $32-42$ & $1.55-2.00$ & $1.39-1.80$ & $0.314-0.453$ & $0.354-0.436$ & $1.08-1.35$ & Limanda yokohamae & $\begin{array}{l}\text { Otsuchi bay of } \\
\text { Japan }\end{array}$ \\
\hline $\begin{array}{l}\text { Clavinema mariae } \\
\text { (Margolis \& Moravec } \\
[12])\end{array}$ & $24-48$ & $0.74-1.96$ & $0.96-1.44$ & $0.202-0.326$ & $0.235-0.398$ & $0.74-1.18$ & Cottus asper & $\begin{array}{l}\text { Vancouver } \\
\text { Island, B.C., } \\
\text { Canada }\end{array}$ \\
\hline
\end{tabular}

$\mathrm{mm}$. The uterus extended anteriorly to the midpoint of the esophagus and did not contain eggs or embryos. The posterior ovary was directed anteriorly. The posterior end of the body was rounded without any projections or papillae. Variations in morphometric data of $C$. mariae are shown in Table 1.

Differential keys used in the taxonomy of the family Philometridae are based on the structure of the esophagus, the number, arrangement, and character of the cephalic papillae in females, the structure of cuticular ornamentations on the body, and the shape of the tail [11]. Species of the genus Clavinema have a well-developed anterior esophageal bulb, which is distinctly separated from the cylindrical portion of the esophagus, and a very small esophageal gland at the mid-length of the cylindrical portion of the esophagus [12]. In this study, the female philometrid nematodes were morphologically identical to those previously isolated from the benthic fishes Rhinogobius pflaumi and Chaeturichys sciistius [13], the right-eyed flounder, Limanda yokohamae [14], and the prickly sculpin, Cottus asper, in Canada [12]. The parasite discovered in this study was identified as C. mariae based on a number of characters, including the body shape, absence of a caudal projection, presence of a cylindrical-shaped esophagus, and a well-developed anterior bulbous part of the esophagus. Although Moravec [3] described C. mariae as having 14 small cephalic papillae, not all of them were observed in the present specimens. To date, there have been no published scanning electron micrographs showing 14 cephalic papillae in C. mariae. Sokolov et al. [15], however, presented the putative papillae of $C$. mariae isolated from 
Pacific saffron cod. The specimens examined in the present study were smaller than those isolated from R. pflaumi, C. sciistius, and $C$. asper, which could be attributable to the fact that the sub-gravid females were taken from fish sampled in June. Unfortunately, it is difficult to obtain sufficient numbers of gravid females for identification because they emerge from their hosts from July to August.

C. mariae was first reported in 1930 by Layman as Philometra mariae, found on the fins of Protopsetta herzensteini and Limanda schrenki in Peter the Great Bay, Sea of Japan [16]. In 1970, Machida [14] characterized encapsulated nematodes isolated from the fin and operculum of a right-eyed flounder, Limanda yokohamae, as $P$. mariae. He insisted that the genus Clavinema is valid and that $P$. mariae should be transferred to the genus $\mathrm{Cla}$ vinema. Margolis and Moravec [12] advocated that Clavinema should be accepted as a valid genus and thus $C$. mariae is conspecific with P. mariae Layman, 1930, Philometra americana Kuitunen-Ekbaum, 1933, and Philometra zebrini Yamaguti, 1961.

The life cycle of philometrids involves a copepod as an intermediate host [3]. The development of $C$. mariae was studied by Sakaguchi and Fukuhara [17], who reported that after the larvae are ingested by copepods, such as Tigriopus japonicus, they penetrate through the gut wall and into the hemocoel, where they develop into third-stage larvae. Previous studies have suggested that $C$. mariae infects mainly benthic fish with exception of the pelagic Pacific saffron cod [12-16] (Table 1). In Korea, infection by C. mariae was detected only in Cheonsuman Bay, where the water depth is typically shallow ( $5 \mathrm{~m}$ or less). Areas for future study include examining the route of infection of $C$. mariae in Korea and determining how to control this parasite, while taking the local environment of Cheonsuman into account.

In conclusion, the nematode discovered in rockfish is morphologically similar to C. mariae in terms of the body shape, absence of a caudal projection, presence of a cylindrical-shaped esophagus, and a well-developed anterior bulbous part of the esophagus. In addition, this study presents scanning electron micrographs of the cephalic papillae and light microscope images of the esophageal gland. To the best of our knowledge, this study is the first to report the identification of C. mariae from cultured rockfish in Korea.

\section{ACKNOWLEDGMENT}

This work was supported by the National Institute of Fisher- ies Science (no. R2017064).

\section{CONFLICT OF INTEREST}

We have no conflict of interest related to this work.

\section{REFERENCES}

1. KOSIS [Internet]. Korean Statistical Information Service [cited 2014 July 7]. Available from: http://kosis.kr/.

2. Seo HG, Seo JS, Ryu MK, Lee EH, Kwon SR, Kang JS, No YS, Choi HS, Jung HS, Han HJ. A nematode infection in the epithelial tissue of cultured rockfish Sebastes schlegeli in Cheonsu Bay, Western Korea. Korean J Fish Aquat Sci 2014; 47: 603-610.

3. Moravec F. Some aspects of the taxonomy and biology of dracunculoid nematodes parasitic in fishes: a review. Folia Parasitol 2004; 51: $1-13$

4. Moravec F, Nagasawa K, Nohara K. Two species of philometrid nematodes (Philometridae) from marine fishes off Japan, including Philometroides branchiostegi sp. n. from Branchiostegus japonicus (Malacanthidae). Folia Parasitol 2012; 59: 71-78.

5. Conboy GA, Speare DJ. Dermal nematodosis in commercially captured rockfish (Sebastes spp.) from coastal British Columbia, Canada. J Comp Pathol 2002; 127: 211-213.

6. Moravec F, Conboy GA, Speare DJ. A new trichosomoidid from the skin of Sebastes spp. (Pisces) from British Columbia, Canada. J Parasitol 2005; 91: 411-414.

7. Deardorff TL, Throm R. Commercial blast-freezing of third-stage Anisakis simplex larvae encapsulated in salmon and rockfish. J Parasitol 1988; 74: 600-603.

8. Strømnes E, Andersen K. "Spring rise" of whaleworm (Anisakis simplex; Nematoda, Ascaridoidea) third-stage larvae in some fish species from Norwegian waters. Parasitol Res 2000; 86: 619-624.

9. Strømnes E, Andersen K. Growth of whaleworm (Anisakis simplex, Nematodes, Ascaridoidea, Anisakidae) third-stage larvae in paratenic fish hosts. Parasitol Res 2003; 89: 335-341.

10. Klapper R, Kuhn T, Münsterb J, Levsenc A, Karla H, Klimpel S. Anisakid nematodes in beaked redfish (Sebastes mentella) from three fishing grounds in the North Atlantic, with special notes on distribution in the fish musculature. Vet Parasitol 2015; 207: 72-80.

11. Rasheed S. A revision of the genus Philometra Costa, 1845. J Helminthol 1963; 38: 89-130.

12. Margolis L, Moravec F. A record of Clavinema mariae (Layman, 1930) (Nematoda: Philometridae) from a North American freshwater fish, with notes on the systematic status of Philometra americana Kuitunen-Ekbaum, 1933. Folia Parasitol 1987; 34: 31-36.

13. Yamaguchi Y, Sakaguchi S, Goro M. Studies on a nematode, Philometra, in the marine benthic fishes-I. Distribution in the Northwest areas of Hiroshima bay. Morphological observations on the adult nematode. Bull Nansei Reg Fish Res Lab 1973; 6: 9-16 (in Japanese). 
14. Machida M. Philometra mariae Layman, 1930 from a right-eyed flounder, Limanda yokohamae. Fish Pathol 1970; 5: 21-24 (in Japanese).

15. Sokolov SG, Frolova SE, Frolov EV. The first record of parasitic nematode Clavinema mariae (Dracunculoidea: Philometridae) in gadiform fishes (Osteichthyes: Gadiformes). Inverteb Zool 2010; 7: 123-132 (in Russian).
16. Layman EM. Parasitic worms from the fishes of Peter the Great Bay. Bull Pacific Sci Fish Res Stat 1930; 3: 98-99.

17. Skaguchi S, Fukuhara O. Studies on a nematode, Philometra, in the marine benthic fishes, 2: Morphology of the larvae and experimental infection to the intermediate host. Bull Nansei Reg Fish Res Lab 1975; 8: 1-10 (in Japanese). 